\title{
Analysis Of Community Potential In Flood And Environmental Disease Prevention In Banjar District
}

\author{
Syamsul Arifin', Lenie Marlinae, Danang Biyatmoko ${ }^{3}$, Chairul Irawan ${ }^{3}$, Husaini ${ }^{4}$, Abdi Fithria ${ }^{5}$, Akmad Rizalli \\ Saidy $^{3}$, M Gilmani ${ }^{2}$, Fairuz Nur Fawaz ${ }^{2}$, Noor Laila Afifah², Ammara Ulfa Azizah ${ }^{2}$ \\ ${ }^{1}$ Master Program in Public Health Sciences, Faculty of Medicine, Lambung Mangkurat University \\ ${ }^{2}$ Public Health Study Program, Faculty of Medicine, Lambung Mangkurat University \\ ${ }^{3}$ Master's Program in Natural Resources and Environmental Management Prog. Postgraduate Lambung Mangkurat University \\ ${ }^{4}$ Master Program in Public Health Sciences, Faculty of Medicine, Lambung Mangkurat University \\ ${ }^{5}$ Banjarbaru Health Polytechnic
}

DOI: 10.29322/IJSRP.11.11.2021.p11933

http://dx.doi.org/10.29322/IJSRP.11.11.2021.p11933

\begin{abstract}
Data from the Regional Disaster Management Agency (BPBD) of South Kalimantan Province (2018) total disaster events in the South Kalimantan Region. As of January 27, 2021, there were 227 disasters recorded. The dominant natural disaster is flood disaster. The flood disaster caused a death toll of 259 people (dead and missing) and 8 missing and 3,654 people injured. The purpose of this study is to analyze the relationship between flood prevention activities and community institutions that play a role in flood prevention and the relationship between flood prevention activities and the potential of natural resources in flood prevention in Banjar Regency. This research method consists of three stages, that are a preliminary survey, data collection, and data analysis. The results showed that there was a relationship between flood prevention activities and community institutions that play a role in flood prevention $(\mathrm{p}<0.05)$ and there was no relationship between flood prevention activities and the potential of natural resources in flood prevention ( $\mathrm{p} \geq 0.05$ ).
\end{abstract}

Index Terms- Flood, flood prevention, community institutions, community resources

\section{INTRODUCTION}

$\mathrm{F}$ ood is an ordinary natural phenomenon, but it will be very detrimental if it threatens the existence of human life. Floods that occur are caused by heavy and continuous rain and seasonal irregularities marked by the Elnino phenomenon (prolonged dry season) and Lanina, namely rain that falls continuously (Purwani, Fridani and Fahrurrozi, 2019).

South Kalimantan is one of the provinces in Indonesia which is a province that has a high risk of flooding in terms of its physical condition. Physical conditions in South Kalimantan are mostly inundated during high rainfall. The water level when a flood occurs reaches 2-3 meters. Geographically, most of South Kalimantan is below sea level causing the water flow on the land surface to be less smooth. In addition to geographical factors, the cause of flooding is also due to rampant coal mining in the upstream and illegal logging (Angriani and Kumalawati, 2016).

As of January 27, 2021, there were 227 disasters recorded. The natural disasters that dominate are floods, followed by hurricanes and landslides. The flood disaster caused a death toll of
259 people (dead and missing) and 8 missing and 3,654 people injured. As many as 42,762 houses were damaged, facilities (education, worship, health) were damaged as many as 1,542, offices were damaged as many as 134 , and bridges were damaged as many as 442 , refugees as many as $1,517,935$ people (BNPB, 2021). Determination of Emergency Response Status Number: $188.44 / 058 / \mathrm{KUM} / 2021$ which is valid from January 14, 2021 to January 27, 2021 and has been extended by Decree of the Governor of South Kalimantan Number: 188.44/085/KUM/2021 concerning Extension of Decree on Emergency Response for floods, land disasters landslide, hurricane, and tidal waves in South Kalimantan Province, from January 28, 2021 to February 3, 2021 (Jati, 2021)

Based on the 2018 Basic Health Research (Riskesdas) it was shown that in Banjar Regency the use of clean water per person per day was $2.41 \%$. And the comparison of the use of clean water that is less due to the lack of clean water sources between urban $1.90 \%$ and rural $2.50 \%$ is approximately only $0.6 \%$ different(Ministry of Health, 2018). Based on this background, researchers are interested in conducting research to analyze the potential factors of the community's ability (potential knowledge of the community, potential community resources, potential risk areas and community institutions that play a role) in flood prevention in Banjar Regency. It is hoped that with this research, it is hoped that the potential of the community in Banjar Regency in preventing flooding can be known.

\section{METHOD}

This research method consists of three stages, namely the preliminary survey stage, the stage of collecting through FGD and data processing and the stage of calculating and analyzing data. Preliminary survey to obtain an overview of the research location, data collection consists of primary and secondary data, and at the data analysis stage to answer 4 objectives, namely analyzing the potential for community knowledge related to clean water management, community resources, risk areas, community institutions in preventing floods and diseases environment based in Banjar Regency. 


\section{FINDING}

\section{Respondent Characteristics}

Table 1. Frequency Distribution of Age Category

\begin{tabular}{lll}
\hline Age & Frequency & Percentage (\%) \\
\hline Late teens & 3 & 10 \\
\hline Early adult & 9 & 30 \\
\hline Late adult & 14 & 46.7 \\
\hline Early elderly & 1 & 3.3 \\
\hline Late elderly & 2 & 6.7 \\
\hline Elderly & 1 & 3.3 \\
\hline Total & $\mathbf{3 0}$ & $\mathbf{1 0 0}$ \\
\hline
\end{tabular}

According to the Ministry of Health, the age category is divided into the late teen age category (17-25 years), the early adult age category (26-35 years), the late adult age category (3645 years), the early elderly age category (46-55 years), 56-65 late elderly, and seniors $>65$. Based on Table 1 it is known that as many as 3 respondents (10\%) in the late teen category, as many as 9 respondents $(30 \%)$ in the early adult category, as many as 14 respondents $(46.7 \%)$ in the late adult category, 1 respondent (3.3\%) was in the early elderly category, 2 respondents $(6.7 \%)$ was in the late elderly category and 1 respondent $(3.3 \%)$ was in the elderly category.

Table 2. Frequency Distribution of Gender Category

\begin{tabular}{lll}
\hline Gender & Frequency & $\begin{array}{l}\text { Percentage } \\
(\boldsymbol{\%})\end{array}$ \\
\hline Male & 14 & 46.7 \\
\hline Female & 16 & 53.3 \\
\hline Total & $\mathbf{3 0}$ & $\mathbf{1 0 0}$ \\
\hline
\end{tabular}

Based on Table 2, it is known that as many as 14 respondents (46.7\%) are male and 16 respondents (53.3\%) are female.

\section{Table 3. Education Frequency Distribution}

\begin{tabular}{lll}
\hline Education & Frequency & Percentage (\%) \\
\hline $\begin{array}{l}\text { Not in school/didn't } \\
\text { elementary school }\end{array}$ & 3 & 10 \\
\hline Elementary school & 8 & 26.7 \\
\hline Junior high school & 10 & 33.3 \\
\hline Senior High School & 7 & 23.3 \\
\hline Academics/College & 2 & 6.7 \\
\hline Total & $\mathbf{3 0}$ & $\mathbf{1 0 0}$ \\
\hline
\end{tabular}

Based on Table 5.3 it is known that as many as 3 respondents (10\%) did not go to school / did not finish elementary school, as many as 8 respondents $(26.7 \%)$ had their last education in elementary school, as many as 10 respondents $(33.3 \%)$ had junior high school, as many as 7 respondents $(23.3 \%)$ His last education was high school and as many as 2 respondents his last education was Academics/College.
Table 4. Income Frequency Distribution

\begin{tabular}{lll}
\hline Income & Frequency & $\begin{array}{l}\text { Percentage } \\
(\boldsymbol{\%})\end{array}$ \\
\hline $2,877,448$ & 16 & 53.3 \\
\hline$<2,877,448$ & 14 & 46.7 \\
\hline Total & $\mathbf{3 0}$ & $\mathbf{1 0 0}$ \\
\hline
\end{tabular}

Based on Table 5.4, it is known that as many as 16 respondents (53.3\%) have an income of 2,877,448 and as many as 14 respondents $(46.7 \%)$ have an income of $<2,877,448$.

\section{Flood Prevention Activities}

Table 5. Distribution of Prevention Activities

\begin{tabular}{lll}
\hline Activity & Frequency & Percentage (\%) \\
\hline Not enough & 21 & 70.0 \\
\hline Good & 9 & 30.0 \\
\hline Total & $\mathbf{3 0}$ & $\mathbf{1 0 0 . 0}$ \\
\hline
\end{tabular}

Based on Table 5, it is known that as many as 21 respondents (70\%) stated that the activities in the village were running poorly and as many as 9 people (30\%) stated that the activities in the village were running well.

3. Potential of Community Resources in Flood Prevention

Table 6. Distribution of Rain Potential

\begin{tabular}{lll}
\hline Rain Potential & Frequency & $\begin{array}{l}\text { Percentage } \\
(\mathbf{\%})\end{array}$ \\
\hline Tall & 27 & 90 \\
\hline Low & 2 & 6.7 \\
\hline Safe & 1 & 3.3 \\
\hline Total & $\mathbf{3 0}$ & $\mathbf{1 0 0}$ \\
\hline
\end{tabular}

Based on Table 6, it is known that as many as 27 respondents $(90 \%)$ stated that the potential for rain in their village was high, as many as 2 respondents $(6.7 \%)$ stated that the potential for rain in their village was low and as many as 1 respondent $(3.3 \%)$ stated that the potential for rain in their village was safe. The potential for rain is high because it usually occurs on a weekly basis.

Table 7. Landslide Potential Distribution

\begin{tabular}{lll}
\hline Landslide Potential & Frequency & Percentage (\%) \\
\hline Safe & 30 & 100 \\
\hline Total & $\mathbf{3 0}$ & $\mathbf{1 0 0}$ \\
\hline
\end{tabular}

Based on Table 7, it is known that as many as 30 respondents $(100 \%)$ stated that the potential for landslides in their village had never occurred. 
Table 8. Distribution of Tornado Potential

\begin{tabular}{lll}
\hline Tornado Potential & Frequency & Percentage (\%) \\
\hline Tall & 1 & 3.3 \\
\hline Low & 2 & 6.7 \\
\hline Safe & 27 & 90 \\
\hline Total & $\mathbf{3 0}$ & $\mathbf{1 0 0}$ \\
\hline
\end{tabular}

Based on table 8 , it is known that the tornado potential is only 1 respondent $(3.3 \%)$ stating that the tornado potential in their village is high, 2 respondents $(6.7 \%)$ are low and as many as 27 respondents $(90 \%)$ are safe. The potential for high and low tornadoes is due to tornadoes that occur in rice fields. This usually happens on a weekly or monthly basis.

Table 9. Distribution of Flood Potential

\begin{tabular}{lll}
\hline Flood Potential & Frequency & Percentage $\mathbf{( \% )}$ \\
\hline Tall & 6 & 20.0 \\
\hline Low & 1 & 3.3 \\
\hline Safe & 23 & 76.7 \\
\hline Total & $\mathbf{3 0}$ & $\mathbf{1 0 0}$ \\
\hline
\end{tabular}

Based on table 9, it is known that the potential for flooding in the high category is 6 respondents (20\%), 1 respondent $(3.3 \%)$ is low and 23 respondents $(76.7 \%)$ are safe. The potential for flooding based on the results of this study does not often occur.

Table 10. Distribution of Fallen Tree Potential

\begin{tabular}{lll}
\hline Fallen Tree Potential & Frequency & Percentage (\%) \\
\hline Low & 1 & 3.3 \\
\hline Safe & 29 & 96.7 \\
\hline Total & $\mathbf{3 0}$ & $\mathbf{1 0 0}$ \\
\hline
\end{tabular}

Based on Table 10, it is known that as many as 1 respondent $(3.3 \%)$ stated that the potential for falling trees in their village was low and as many as 29 respondents $(96.7 \%)$ stated that the potential for falling trees in their village was safe/no fallen trees.

Table 11. Distribution of Damaged Bridge Potential

\begin{tabular}{lll}
\hline Broken Bridge Potential & Frequency & Percentage (\%) \\
\hline Low & 2 & 6.7 \\
\hline Safe & 28 & 93.3 \\
\hline Total & $\mathbf{3 0}$ & $\mathbf{1 0 0}$ \\
\hline
\end{tabular}

Based on Table 11, it is known that as many as 2 respondents $(6.7 \%)$ stated that the potential for damaged bridges in their village was low and 28 respondents $(23.3 \%)$ stated that the potential for damaged bridges in their village was safe.

Table 12. Distribution of Natural Resources Potential in Flood Prevention

\begin{tabular}{lcl}
\hline $\begin{array}{l}\text { Natural } \\
\text { Potential }\end{array}$ & Resources $_{\text {Frequency }}$ & Percentage (\%) \\
\hline Low & 6 & 20 \\
\hline
\end{tabular}

This publication is licensed under Creative Commons Attribution CC BY.

http://dx.doi.org/10.29322/IJSRP.11.11.2021.p11933

\begin{tabular}{lll}
\hline Safe & 24 & 80 \\
\hline Total & $\mathbf{3 0}$ & $\mathbf{1 0 0}$ \\
\hline
\end{tabular}

Based on Table 12, it is known that the respondents who stated that the potential of natural resources were included in the low category were 6 respondents $(20 \%)$ and as many as 24 respondents $(80 \%)$ stated that the potential of natural resources was in the safe category. The potential of natural resources in this study is the potential for rain, landslides, cyclones, floods, fallen trees and damaged bridges. The low potential of natural resources is the potential of natural resources that occurs every month while the potential of safe natural resources is the potential of natural resources that rarely or never occurs.

\section{Knowledge of Community Institutions}

Table 13. Distribution of Community Institution Category

\begin{tabular}{lll}
\hline Community Institutions & Frequency & Percentage (\%) \\
\hline Not enough & 24 & 80 \\
\hline Good & 6 & 20 \\
\hline Total & $\mathbf{3 0}$ & $\mathbf{1 0 0}$ \\
\hline
\end{tabular}

Based on Table 13, it is known that as many as 24 respondents $(80 \%)$ stated that the community institutions in their village were lacking and as many as 6 respondents (20\%) stated that the community institutions in their village were good.

\section{Statistical Test Analysis}

Table 14. Relations with Community Institutions Playing a Role in Flood Prevention Activities

\begin{tabular}{|c|c|c|c|c|c|c|c|}
\hline \multirow{3}{*}{$\begin{array}{l}\text { Community } \\
\text { Institutions }\end{array}$} & \multicolumn{4}{|c|}{$\begin{array}{l}\text { Flood Prevention } \\
\text { Activities }\end{array}$} & \multirow{2}{*}{\multicolumn{2}{|c|}{ Total }} & \multirow{3}{*}{$\begin{array}{l}\text { p- } \\
\text { value }\end{array}$} \\
\hline & \multicolumn{2}{|c|}{$\begin{array}{l}\text { Not } \\
\text { enough }\end{array}$} & \multicolumn{2}{|c|}{ Good } & & & \\
\hline & $\mathbf{n}$ & $\%$ & $\mathbf{n}$ & $\%$ & $\mathbf{n}$ & $\%$ & \\
\hline Not enough & 20 & 83.3 & 4 & 16.7 & 24 & 100 & 0.005 \\
\hline Good & 1 & 16.7 & 5 & 83.3 & 6 & 100 & 0.005 \\
\hline
\end{tabular}

Based on table 14, it is known that flood prevention activities that more or less occur in community institutions that have less role are as many as 20 respondents $(83.3 \%)$ compared to community institutions that play a good role only 1 respondent $(16.7 \%)$. While good flood prevention activities mostly occur in community institutions that have a good role as many as 5 respondents $(83.3 \%)$ compared to community institutions that have less role as many as 4 respondents $(16.7 \%)$.Fisher exact test results in table 17 show that $\mathrm{p}$-value $=0.005$. Based on the $\mathrm{p}$-value in the statistical test results, it was concluded that Ho was rejected $(p<0.05)$, which means that there is a relationship between flood prevention activities and community institutions that play a role in flood prevention. 
Table 15. Relationship of Natural Resources Potential with Flood Prevention Activities

\begin{tabular}{|c|c|c|c|c|c|c|c|}
\hline \multirow{3}{*}{$\begin{array}{l}\text { Natural } \\
\text { Resources } \\
\text { Potential }\end{array}$} & \multicolumn{2}{|c|}{$\begin{array}{l}\text { Flood } \\
\text { Activities }\end{array}$} & \multicolumn{2}{|c|}{ Prevention } & \multirow{2}{*}{\multicolumn{2}{|c|}{ Total }} & \multirow{3}{*}{$\begin{array}{l}\text { p- } \\
\text { value }\end{array}$} \\
\hline & \multicolumn{2}{|c|}{$\begin{array}{l}\text { Not } \\
\text { enough }\end{array}$} & \multicolumn{2}{|c|}{ Good } & & & \\
\hline & $\mathbf{n}$ & $\%$ & $\mathbf{n}$ & $\%$ & $\mathbf{n}$ & $\%$ & \\
\hline Low & 5 & 83.3 & 1 & 16.7 & 6 & 100 & \\
\hline Safe & 16 & 66.7 & 8 & 33.3 & 24 & 100 & 0.6 \\
\hline
\end{tabular}

Based on table 15, it is known that flood prevention activities which more or less occur in low natural resource potentials are 5 respondents $(83.3 \%)$ compared to 16 respondents $(66.7 \%)$. While good flood prevention activities mostly occur in safe natural resource potential as many as 8 respondents $(33.3 \%)$ compared to low natural resource potential as many as 1 respondent $(16.7 \%)$.Fisher exact test results in table 5.18 show that $\mathrm{p}$-value $=$ 0.637. Based on the p-value in the statistical test results, it was concluded that Ho was rejected ( $\mathrm{p} \geq 0.05)$, which means that there is no relationship between flood prevention activities and the potential of natural resources in flood prevention.

\section{DISCUSSION}

\section{Relationship of Natural Resources Potential with} Flood Prevention Activities

The results of this study indicate that there is no relationship between the potential of natural resources and flood prevention activities ( $\mathrm{p}$-value $=0.637$ ). The potential natural resources studied in this study are rain, landslides, cyclones, floods, fallen trees and damaged bridges. Climate change has the potential to intensify flood risk in a city in three ways: higher sea levels and storm surges, higher than normal rainfall, and changes in river flow that tend to increase, for example due to glacial melt. Heavy rainfall is a major factor in the occurrence of floods. The inability of the soil to absorb rainwater quickly which inundates the expanse of land causes flooding. The rivers are unable to accommodate the rainfall, in addition to the flow which may have been blocked causing flash overflows to inundate the land. Floods usually always hit when the intensity and rainfall are high, but the lack of public awareness and knowledge about floods often causes problems, such as the lack of alertness of residents when floods occur (Faisal, 2019).

In addition, the potential for landslides based on the results of this study is included in the safe category, namely landslides rarely or never occur. Landslide is a mass movement of soil or rock or both, which descends the slope due to the soil or rock making up the slope experiencing disturbance or instability. Landslide is a process of mass transfer of soil or rock in an oblique direction from its original state, resulting in a steady mass separation due to the influence of gravity with the type of movement in the form of rotation and translation (Nella et al, 2021). The cause of landslides is the decline in environmental quality and sustainable functions of the area and causes the threat of flooding (Rizkiah et al, 2015).
The results of this study stated that the potential for tornadoes was mostly included in the safe category, but there were several areas where tornadoes occurred in the rice fields in Kelampapan Ulu Village. According to the Regulation of the Head of BMKG Number: Kep.009 of 2010 that a tornado is a rotating strong wind that comes out of Cumulonimbus clouds with a speed of more than 34.8 knots or $64.4 \mathrm{~km} /$ hour and occurs in a short time. Tornadoes move in a circular fashion in a spiral turning counterclockwise in the southern region of the equator. Tornado weather phenomenon comes from Cumulonimbus clouds. However, not all Cumulonimbus clouds can cause tornadoes. Waterspouts and tornadoes are the same, the only difference is where they occur. This tornado weather phenomenon is local so it is difficult for forecasters to predict. To make it easier for forecasters to provide related weather information, a study was conducted on the use of global model data, satellite imagery, and upper air observation data in the identification of tornado and waterspout events (Alexandra, 2017). Convective clouds including Cumulonimbus $(\mathrm{Cb})$ can produce heavy (extreme) rainfall in an area so that it can cause flooding, especially when the Inter Tropical Convergence Zone (ITCZ) is in Indonesian territory (Sinta, 2017).

The potential for fallen trees in this study is mostly included in the safe category, which is rarely or never the potential for falling trees occurs. The high potential for falling tree disasters in residential areas often occurs, especially before the rainy season. This potential disaster in the form of the danger of a fallen tree is a disaster that can be anticipated in advance. Anticipation can be done through maintenance management and regular monitoring of tree development. The occurrence of this fallen tree disaster is often the result of a post-hurricane disaster. In addition to hitting objects that are around it, it is not uncommon for fallen trees to take lives. This is because the position of the fallen tree is in public spaces that are passed by the community every day. Various kinds of losses have been recorded as a result of falling trees, apart from the loss of life, fallen trees can damage infrastructure facilities and infrastructure (Aritama AAN, 2019).

The results of this study state that the potential for damaged bridges is included in the safe category, which is rare. Floods affect various sectors of life. Floods can be regarded as a disaster, because the impact it causes is very broad. The impact of floods on the physical environment, where the floods that occur have a very large impact on the physical environment, including floods that can cause damage to bridges, roads and house buildings, damage agricultural fields and so on. Bridges as a means of transportation have a very important role for the smooth movement of traffic. Where the function of the bridge is to connect separate transportation routes or trajectories either by rivers, swamps, lakes, straits, channels, highways, railways and other crossings. Bridges have a very important role in supporting the existing land transportation system, so bridges must be made strong and not easily damaged (Hairil A and Slamet I, 2021).

\section{Relationship between Community Institutions and Flood Prevention Activities}

The results of this study indicate that there is a relationship between community institutions that play a role in flood prevention activities $(\mathrm{p}$-value $=0.005)$. The results of this study state that existing community institutions or policies are involved institutions such as youth organizations. As for funds, in the event 
of a disaster, use emergency funds/unexpected funds. Based on the results of previous research, it was found that disaster management carried out in Jatinangor District was seen about the actions taken by the Jatinangor Emergency Response Community (Jersey) at the pre-disaster, during disaster, and post-disaster stages. Pre-disaster activities include prevention, mitigation, early warning and make efforts to prevent flood disasters such as community service cleaning the environment and garbage that clogs river channels. Activities during a disaster include emergency response activities to relieve the affected victims, distribution of aid, evacuation, and search and rescue. Post-disaster activities are encouraging the community to clean the environment from flood debris such as garbage and scattered mud (Fedryansyah et al., 2018).

There is a role from the surrounding community in disaster management efforts through awareness of the dangers of flooding by creating a community organization called the Indonesian Volunteer Community. This community organization received assistance in the form of facilities and infrastructure from the private sector in the form of the establishment of a post and evacuation equipment. MRI provides the public with information about the status of the altitude so that the community can immediately prepare for the flood disaster. In addition, the community has done self-help to patch the cracked and leaking embankments (Muhammad and Yaya, 2020).

Based on the results of previous research, if it rains heavily, the activities of local residents are disrupted if the rain exceeds the capacity of the river, the local residents are prepared to move valuables to be moved to a higher place. Residents who usually work every morning to go to work have to wade through the water that flows into their homes. Not to mention, the sewers are clogged due to the large amount of garbage that prevents the water from flowing and clogged causing the water to overflow and this unwanted thing happened, most of the school children were also constrained because of the flood. This incident might not have happened if residents in RT 2 RW 3 Kelurahan Sungai Lakam Timur worked together to clean up ditches and rivers that were previously blocked could flow as usual (Razalo and Dewy, 2020). This helps the community in forming and planning what actions need to be taken during a flood. Community participation must be carried out in an organized and coordinated manner so that it can be carried out effectively. A community organization should be formed to take early actions and regulate community participation in flood problems. This is done to increase public knowledge in dealing with flooding while reducing its impact (Razalo and Dewy, 2020).

\section{CONCLUSION}

\section{Conclusion}

The results of this study stated that as many as 13 respondents $(43.3 \%)$ of the community had less knowledge of clean water management and as many as 17 respondents $(56.7 \%)$ of the community had good knowledge of clean water treatment. The results of statistical test analysis in this study found that:

a. $\quad$ Fisher exact test results show that $p$-value $=0.005$.

Based on the p-value in the statistical test results, it was concluded that Ho was rejected $(\mathrm{p}<0.05)$, which means that there is a relationship between flood prevention activities and community institutions that play a role in flood prevention.

b. $\quad$ Fisher exact test results show that $\mathrm{p}$-value $=0.637$. Based on the p-value in the statistical test results, it was concluded that Ho was rejected ( $p \geq 0.05)$, which means that there is no relationship between flood prevention activities and the potential of natural resources in flood prevention.

\section{Suggestion}

a. The need to increase knowledge about clean water management in the community to kill bacteria and to remove chemicals in water, especially clean water treatment during flood disasters in Banjar Regency

b. The need for flood prevention efforts by providing information related to disaster management with clean water management for local communities in Banjar Regency

c. The need to know natural resources in efforts to manage clean water in the people of Banjar Regency

d. The need for the establishment of institutions that are responsible for preventing floods and environmentalbased diseases in Banjar Regency

\section{REFERENCES}

[1] Afrianita, Reri dkk. 2017. Analisis Intrusi Air Laut dengan Pengukuran Total Dissolved Solid (TDS) Air Sumur Gali di Kecamatan Padang Utara. Jurnal Teknik Lingkungan UNAND

[2] Angriani, F. and Kumalawati, R. (2016) ,,pemetaan bahaya banjir kabupaten hulu sungai tengah provinsi kalimantan selatan"e, Jurnal SPATIAL Wahana Komunikasi dan Informasi Geografi. doi: 10.21009/spatial.162.03.

[3] Aritama AAN. (2019). Penanganan bencana pohon tumbang dalam konteks manajemen perkotaan di Kabupaten Badung. Jurnal Manajemen Aset Infrastruktur \& Fasilitas; 3(1): 33-42.

[4] Dwiratna S, Boy M.P., Dwi R.K. (2018). Pemberdayaan masyarakat dalam pengolahan air banjir menjadi air baku di daerah rawan banjir. Jurnal Aplikasi Ipteks untuk Masyarakat, 7(1): 75-79.

[5] Faisal. (2019). Pengelolaan air hujan sebagai strategi pencegahan bencana sejak dini. Edukasi Jurnal MPD; 3(2): 24-42.

[6] Fedryansyah M., Ramadhan P., Ishartono. (2018). Penanggulangan bencana oleh organisasi lokal di Kecamatan Jatinangor. Social Work Jurnal, 8(2): 136141

[7] Hairil A, Slamet I, Matius P. (2021). Rapid health assesment (RHA) bencana banjir di Desa Pranti Kecamatan Menganti Kabupaten Gresik. Healthy Papua; 4(1): 200-205.

[8] Jati, D. R. (2021) Update Penanganan Banjir Kalimantan Selatan 2021 Jakarta.

[9] Kementerian Kesehatan, R. (2018) „Laporan riskesdas Provinsi Kalimantan Selatan $2018^{\circ e}$, Badan Penelitian dan Pengembangan Kesehatan Kementerian Kesehatan RI.

[10] Lindawati, Wasludin. (2017). Pengetahuan dan sikap tentang bencana banjir terhadap kesiapsiagaan dalam kesehatan pada masyarakat RW 05 RT 01 dan RT 03 Kelurahan Gondrong Kota Tangerang. Jurnal Medikes, 4(2): 195-202.

[11] Muhammad F.I., Yaya M.A.A. (2020). Implementasi kebijakan dalam mitigasi bencana banjir di Desa Dayeuhkolot. Jurnal Ilmu Administrasi, 11(1): 50-60.

[12] Nastiti RP, Rafiah MP. (2021). Faktor-faktor yang berhubungan dengan kesiapsiagaan masyarakat dalam menghadapi bencana banjir di Kelurahan Kebon Pala Jakarta Timur. Poltekita: Jurnal Ilmu Kesehatan; 15(1): 48-56.

[13] Nella WS, Arief LN, Moehammad A. (2021). Analisis Ancaman Terhadap Bencana Banjir dan Tanah Longsor pada Wilayah Permukiman di Kabupaten Jepara. Jurnal Geodesi. 10(2): 25-35. 
[14] Pratama R, Iswandi U. (2020). Mitigasi bencana banjir di Desa Pulau Permai Kecamatan Tambang Kabupaten Kampar Provinsi Riau. Jurnal Buana, 4(6): 1280-1289.

[15] Purwani, A., Fridani, L. and Fahrurrozi, F. (2019) „Pengembangan Media Grafis untuk Meningkatkan Siaga Bencana Banjire", Jurnal Obsesi : Jurnal PendidikanAnak Usia Dini. doi: 10.31004/obsesi.v3i1.142.

[16] Razalo M.T., Dewy S. (2020). Partisipasi masyarakat dalam mengatasi banjir di Kelurahan Sungai Lakam Timur Kecamatan Karimun Kabupaten Karimun (studi kasus di wilayah RT 002 RW 003). Jurnal Kemunting, 1(1): 84-104.

[17] Rizkiah R, Hanny P, Supardjo. (2015). Analisis Faktor-faktor penyebab banjir di kecamatan tikala kota manado. SPASIAL, 1(1), 105-112.

[18] Sinta Berliana Sipayung. (2017). Analisis Awan Cumulonimbus Dan Angin Serta Keterkaitannya Dengan Curah Hujan Di Kawasan Gede Bage, Bandung (Jawa Barat) Berita Dirgantara. 18(2): 75-82.

\section{AUTHORS}

First Author - Syamsul Arifin, Master Program in Public Health Sciences, Faculty of Medicine, Lambung Mangkurat University Second Author - Lenie Marlinae, Public Health Study Program, Faculty of Medicine, Lambung Mangkurat University
Third Author - Danang Biyatmoko, Master's Program in Natural Resources and Environmental Management Prog. Postgraduate Lambung Mangkurat University

Fourth Author - Chairul Irawan, Master's Program in Natural Resources and Environmental Management Prog. Postgraduate Lambung Mangkurat University

Fifth Author - Husaini, Master Program in Public Health Sciences, Faculty of Medicine, Lambung Mangkurat University 5Banjarbaru Health Polytechnic

Sixth Author - Abdi Fithria, Master Program in Public Health Sciences, Faculty of Medicine, Lambung Mangkurat University 5Banjarbaru Health Polytechnic

Seventh Author - Akmad Rizalli Saidy, Master's Program in Natural Resources and Environmental Management Prog. Postgraduate Lambung Mangkurat University

Eight Author - M Gilmani, Public Health Study Program, Faculty of Medicine, Lambung Mangkurat University Nine Author - Fairuz Nur Fawaz, Public Health Study Program, Faculty of Medicine, Lambung Mangkurat University Tenth Author - Noor Laila Afifah, Public Health Study Program, Faculty of Medicine, Lambung Mangkurat University Eleventh Author - Ammara Ulfa Azizah, Public Health Study Program, Faculty of Medicine, Lambung Mangkurat University 